\title{
Effectiveness of Health Promotion Strategies on Malaria Preventive Behaviors in Woyla Public Health Centers (Puskesmas)
}

\author{
${ }^{1}$ Maiza Duana, ${ }^{1}$ Dian Fera, ${ }^{1}$ Danvil Nabela, ${ }^{2}$ Tri Mulyono Herlambang, ${ }^{2}$ Anasril \\ ${ }^{1}$ Faculty of Public Health, Universitas Teuku Umar, Indonesia \\ ${ }^{2}$ Poltekkes Ministry of Health Aceh, Indonesia \\ Corresponding author: Maiza Duana, maizaduana@utu.ac.id \\ Co-author: DF:dianfera@utu.ac.id, DV:danvilnabela91@gmail.com, TMH: trimulyono216@gmail.com, AN: \\ anasrilsuri@gmail.com \\ Submitted:30/08/2021 Revised: 23/09/2021 Accepted: 27/09/2021 Published online: 23/10/2021
}

DOI: https://doi.org/10.35308/j-kesmas.v7i2.4061 How to cite this article: Duana, M., Fera, D., Nabela, D., Herlambang, T.M., \& Anasril. (2021). Effectiveness of Health Promotion Strategies on Malaria Preventive Behaviors in Woyla Public Health Centers (Puskesmas). J-Kesmas: Jurnal Fakultas Kesehatan Masyarakat (The Indonesian Journal of Public Health). 8(2): 86-90.

\begin{abstract}
Malaria is an infectious disease caused by intracellular obligate protozoa of the genus Plasmodium. The disease is naturally transmitted through the bite of a female Anopheles mosquito. West Aceh Regency Is a district with a high incidence of malaria. West Aceh regency ranks second only to Aceh Jaya in terms of the number of malaria sufferers. West Aceh district is also not included in the 14 districts that have been certified for malaria elimination in Aceh Province in 2016. The purpose of this study is to evaluate the effectiveness of health promotion strategies against changes in people's behaviour in preventing malaria in the East Woyla Subdistrict. This type of research is an experimental study with participatory action research (PAR) design, which is a process where researchers and participants systematically dig and solve problems. The population in this study were all community leaders, health workers, health cadres, and the entire community in East Woyla Subdistrict. A sample of 44 people. The sampling method in this study uses a random sampling quota method. Samples will represent each village in East Woyla Sub-district according to the proportion of the population in each village. The results showed that the Health Promotion strategy effectively changed people's behaviour in malaria prevention efforts. The statistical test results showed the value of Z-score $=5,781$ (Z-score $>1.96)$, and $p$-value $=0.000(p<0.05)$. So it can be decided that the community's health promotion strategy is effective against malaria prevention behaviour. It is recommended that the East Woyla Health Center implement a comprehensive and continuous health promotion strategy for the common goal of achieving malaria elimination in its working area of public health.
\end{abstract}

Keywords: Strategy; Health Promotion; Behavioural Health; Malaria

\section{Introduction}

Malaria is an infectious disease caused by intracellular obligate protozoa of the genus Plasmodium. The condition is naturally transmitted through the bite of a female Anopheles mosquito (Arsin. 2012). According to a 2011 World Malaria Report. Estimates of malaria load vary. Each year, malaria is reported to cause more than 250-660 million infections (Cases) and more than one million deaths (M ost of them African children). WHO data mentions that in 2010 there were 544,470 cases of malaria in Indonesia, wherein in 2009 , there were $1,100,000$ clinical cases. In 2010 it increased again to $1,800,000$ cases and received treatment in 2011. In Indonesia, malaria cases were 256,592 people out of 1,322,451 malaria cases examined for blood samples with an annual incidence rate of 1.75/1000 inhabitants. Every 1000 people, there are two people affected by malaria (Ministry of Health RI, 2011).

In Aceh Province itself, it had targeted malaria-free in 2015. Strengthening malaria elimination programs in Aceh Province resulted in significant achievements. West Aceh Regency is a district with a high incidence of malaria. West Aceh regency ranks second only to Aceh Jaya in terms of the number of malaria sufferers. West Aceh district is also not included in the 14 communities that have been certified for malaria elimination in Aceh Province in 2015. One of the districts that are still endemic to malaria in West Aceh District is East Woyla District, with the number of endemic villages as many as ten villages. Based on initial surveys in two villages in East Woyla Subdistrict obtained that interviews and 
observations of researchers, the community does not make preventive efforts in the form of behaviours that support malaria prevention efforts such as mutual assistance to eliminate proper vector breeding, avoid the onset of puddles around the house, mutual aid to eradicate mosquito nests and larvae, use personal protective equipment if out of the house at night (using clothes and trousers, sarongs or using mosquito repellent oils or repellent), sleeping using mosquito nets, installing mosquito nets as prevention of mosquito entry into the house.

Malaria prevention activities are top-down, preferably in case management and the Mass Blood Survey (MBS), which aims to reduce the source of transmission by conducting radical treatment of all malaria-positive patients. Plus, people's behaviour about malaria prevention is not yet supported. Seeing this condition, to reduce malaria incidence in East Woyla Subdistrict, a health promotion approach should be made to improve behaviour. Health promotion in the framework of community empowerment should pay attention to the side of local wisdom where the community has traditions and customs as a potential that can be developed as social capital (social capital) because it can foster mutual trust in cooperation and foster a sense of responsibility (Notoatmodjo, 2012). Health promotion strategy can be done through the following: 1) Advocacy (advocacy), 2) Social support (Social Support), 3) Community Empowerment (Empowerment) (Frank, 2008). This study is an applied study, with the design of Participatory Action Research (PAR), which is a process in which researchers and participants systematically dig and solve problems (KochT. and Kralik D. 2012). This research is a study that actively involves all relevant parties in reviewing ongoing actions (where their own experience is an issue) to make changes and improvements in a better direction. Budiyono's (2010) research on "Stakeholder Positions and District/City Advocacy Strategies in Central Java" states that stakeholders have a strong influence and are highly relevant in advocacy efforts. Program holders more widely know the needs and problems of implementing health promotion activities. Partnership development is carried out

\section{Methods}

This type of research is a pseudo-experiment with participatory action research (PAR) design, which is a process where researchers and participants systematically dig and solve problems. The research population is the whole object of research. The people in this study are all community leaders and all communities in East Woyla Subdistrict. The number of samples is 44 people. The sampling method in this study uses a random sampling quota method. Samples will represent each village in East Woyla Sub-district according to the proportion of the population in each town. The data was collected using behavioural measuring instruments in questionnaires and direct observation of community actions. Questionnaires are prepared following aspects of behaviour to be evaluated, namely knowledge, attitudes, and activities. While comments are made by making observation sheets, which are observed is what has been done to prevent malaria.

The statistical test used is a Wilcoxon test to compare the results of measurements before and after the experiment on the sample group. This bivariate analysis is done using the help of computer programs. This research has obtained permission from the ethics committee of the Health Poltekkes of the Ministry of Health in Aceh

\section{Results}

\section{Characteristics of Respondents}

Table 1. Distribution of Frequency of Respondents Based on Characteristics in The Working Area of East Woyla Health Center, West Aceh District 2017

\begin{tabular}{llll}
\hline No. & category & sum & $\mathbf{( \% )}$ \\
\hline & age & & \\
1 & Young Adult & 10 & 22,7 \\
2 & Middle Adult & 23 & 52,3 \\
3 & Old Adult & 11 & 25,0 \\
\hline \multicolumn{2}{l}{ Total } & 44 & 100 \\
\hline & Level of education & & \\
1 & Bachelor & 7 & 15,9 \\
2 & Senior High School & 23 & 52,3 \\
3 & Junior High School & 9 & 20,4 \\
4 & Primary Shool & 5 & 11,4 \\
\hline & Total & 44 & 100 \\
\hline & work & & \\
1 & Civil Servants & 9 & 20,4 \\
2 & private & 11 & 25,0 \\
3 & farming & 4 & 9,1 \\
4 & Housewife & 20 & 45,5 \\
\hline & Total & 44 & 100 \\
\hline
\end{tabular}

In the table above, it can be known that the majority of respondents are middle adults, namely 23 people $(52.3 \%)$, the most education is high school which is 23 
people $(52.3 \%)$, and most work as housewives that is 20 people $(45.5 \%)$.

Table. 2 Distribution of Frequency of Respondents Based on Malaria Prevention Behaviour Before Health Promotion Strategy Was Implemented in The Working Area of East Woyla Health Center, West Aceh District 2017

\begin{tabular}{llll}
\hline No. & Gategory & Frequency & $\%$ \\
\hline 1 & Good & 15 & 34,1 \\
2 & Less & 29 & 65,9 \\
\hline & Total & 44 & 100 \\
\hline
\end{tabular}

(Primary Data, 2017)

Malaria prevention behaviour by the community is categorized into two categories, namely sound and more petite. Organized if the score obtained is more than the average score, and less when the score received is less than or equal to the average score. Based on the table above, it can be known that before being given a Health Promotion strategy in the form of advocacy, social support, and community empowerment, most respondents have unhealthy behaviour / good behaviour in the prevention of malaria incidence of 29 people $(65.9 \%)$

\section{Implementation of Health Promotion Strategy}

\section{Advocacy}

Advocacy is done by committing with the head of Puskesmas and in charge of Health Promotion to apply policies to the community, especially malaria prevention. According to the director of the health centre and the field of programs, advocacy efforts have also been made in the form of budget requests for health promotion to the public, including the procurement of posters and travel costs for officers who provide Health Promotion. In this advocacy activity, it was agreed that health centres would soon descend to carry out health promotion to malariaprone areas in East Woyla Subdistrict accompanied by researchers.

\section{Social Support}

Social support is an effort to create an opinion or social environment that encourages individual public members to engage in introduced behaviour. In this second strategy, researchers invited health officials and the entire community to form associations such as malaria care groups, and in each meeting, conducted health counselling. The result is creating a collection of malariacaring communities led by health cadres, which has held discussions with the community three times to complete counselling on malaria prevention.

\section{Community Empowerment}

Community empowerment is needed for the community to gain the ability to maintain and improve health. Community empowerment carried out in this research is to activate health cadres not only on posyandu day but also on other days, even dor to dor to observe environmental conditions and provide counselling on malaria prevention.

\section{Malaria Prevention Behaviour After Health Promotion Strategy}

Malaria prevention behaviour by the community is categorized into two categories, namely sound and more negligible. Organized if the score obtained is more than the average score, and less when the score received is less than or equal to the average score. The measurement results can be seen in the following table:

Table 3. Distribution of Frequency of Respondents Based on Malaria Prevention Behaviour After Health Promotion Strategy Implemented in The Working Area of Public Health Woyla Timur West Aceh Regency

\begin{tabular}{llll}
\hline No. & Category & Frequency & \% \\
\hline 1 & Good & 25 & 56,8 \\
2 & Less & 19 & 43,2 \\
\hline \multicolumn{2}{c}{ Total } & 44 & 100 \\
\hline (Primary Data, 2017) & &
\end{tabular}

Based on the table above, it can be known that after being given health promotion strategy in the form of advocacy, social support, and community empowerment, most respondents have good behaviour in the prevention of malaria incidence of 25 people (56.8\%).

\section{Changes in Malaria Prevention Behaviour}

Behaviour changes occur after health promotion strategy, as evidenced by the results of statistical tests such as the table below:

Table 4. Distribution of Frequency of Respondents Based on changes in malaria prevention behaviour score in The Working Area of East Woyla Health Center, West Aceh District 2017 


\begin{tabular}{lccccc}
\hline Variable & n & Mean & $\begin{array}{c}\text { Standard } \\
\text { deviation }\end{array}$ & $\mathbf{Z}$ & P-value \\
\hline Before & 44 & 76,93 & 3,598 & 5,781 & 0,000 \\
After & 44 & 92,86 & 4,163 & & \\
$\begin{array}{l}\text { Average value } \\
\text { difference } \\
\text { (mean) }\end{array}$ & & 15,93 & & & \\
\hline (Primary Data, 2017) & & & & & \\
\hline
\end{tabular}

Based on the table above, before being given the Health Promotion strategy, the average malaria prevention behaviour score was 76.93. After being given the Health Promotion strategy, the average malaria prevention behaviour score was 92.86. The difference in mean value is 15.93 . The pretest-posttest test result using Wilcoxon test obtained a calculated $\mathrm{Z}$ value $=5,781$ (Zcount $>1.96)$, and $p$-value $=0.000(p<0.05)$. So it can be decided that the provision of the Health Promotion Strategy is effective against malaria prevention behaviour by the community.

\section{Discussion}

Behaviour is a person's response or reaction to external stimuli or stimuli. Thus, human behaviour occurs through a process. This theory is called the S-O-R theory or Stimulus-Organism-Response. Convincingly the application of the Health Promotion strategy on an ongoing basis is proven to change people's behaviour in preventing malaria as evidenced by the results of Wilcoxon pre-test and post-test obtained Zvalue count = $5,781$ (Zcount $>1.96)$, and p-value $=0.000(\mathrm{p}<0.05)$.

\section{Advocacy}

This advocacy touches more on policymakers to better know and pay attention to health. Advocacy can be done by influencing policymakers to create regulations that can favour health. Those regulations can create an environment that can affect health behaviours that can be realized in the community. Advocacy activities with full authority implementation can be carried out by Puskesmas, at the sub-district and village level as the working area of Public Health Centre. Public Health can advocate the Sub-District, cross-sector leaders at the subdistrict level, village heads, community leaders, and entrepreneurs in the working area of the public health to obtain the support of personnel, funds, and facilities/health promotion for the prevention of malaria. Suppose public health carries out this advocacy pattern. In that case, this pattern can be expected to overcome or minimize the limitations of facilities, energy, and funds to implement health promotion strategies in malaria prevention efforts. Based on this, this advocacy activity should not stop, meaning it must continue to be pursued for the implementation of activities in the long term in the future

\section{Social Support}

Social support is a form of alignment with various parties to the program or activities implemented in the community. The suitability of community problems makes a positive response to the actions to be made. The support of community leaders, religious leaders, and government figures is expected to bridge between health program managers and the community as the target. Social support strategies need to be established to create conducive norms and conditions/situations supporting malaria prevention efforts. Social support is often associated with social marketing and campaigns since opinion formation requires social marketing activities and campaigns. However, it should be noted that social support is meant to create a supportive atmosphere, mobilize the community participatory and partnership. A person will feel compelled to do something when in a social environment that behaves positively towards their health.

The support of community leaders, religious leaders, and government figures in the East Woyla Subdistrict should be further improved. To explore the participation and support of public figures and government figures, the Puskesmas are expected to understand that health needs more attention. In addition, it is also necessary to realize the element of mutual need between health workers, the community, and the local government to establish profitable cooperation for all.

\section{Community Empowerment}

Empowerment to the community is expected to help the community gain the ability to make decisions and determine the actions that it will take related to themselves, especially health. Empowerment of this community can be done through the power and confidence to use its abilities. The level of knowledge and skills, including community recruitment that still needs to be improved. This is due to the lack of forms of training and health counselling activities to enhance the knowledge and skills of cadres. In addition, the awareness and motivation of the cadres need to be maintained and improved through their active 
participation. These prevention efforts need to be promoted because the household is the smallest part of society, where behavioural changes can significantly impact their lives and health levels. Healthy households are also a key asset and capital of future development that must be maintained, improved, and protected by health.

In the initial planning of community empowerment, we need to pay attention to awareness, clarity, and knowledge of what is empowered and what will be done. In addition, the need for a good understanding of where and who will be assigned, and one of the most critical but often forgotten things, is to ensure the willingness and skills of the community to go through the empowerment process. Families should realize malaria prevention efforts in the household environment to eradicate flicks at home once a week, drain the bathtub, close the water, bury used items that can hold water, sleep using mosquito nets, and so on. Community empowerment can last slowly and long, and it can even be said that it never stops perfectly. That is because. It would be more appropriate if the evaluation were directed at the empowerment process rather than the result. Things that can be evaluated in empowerment are the number of community members who participate in the activities, the number of activities approaching below, the number of actors who feel they are learning while working.

\section{Conclusion}

Based on the results of research and discussions that have been conducted, it can be concluded that the health promotion strategy applied effectively in changing the community's behaviour in malaria prevention efforts. The statistical test results showed the value of Account $=$ 5,781 (Zhit > 1.96), and p-value $=0.000(p<0.05)$. So it can be decided that the community's health promotion strategy is effective against malaria prevention behaviour. It is recommended that the East Woyla Health Center implement a comprehensive and continuous health promotion strategy for the common goal of achieving malaria elimination in its working area. Praise the presence of Allah SWT for His guidance and mercy. Thank you to all those who have helped in the research until this journal is published.

\section{Author Contributions}

The first author had the most significant contributions in this study, from drafting proposals to reporting the results. The second author has contrition in data collection, processing and analysis, and assists the first author in writing articles.

\section{Reference}

Arsin, AA. (2012). Malaria in Indonesia Reviews Epidemiological Aspects. Makasar: Masagena Press

Ministry of Health RI. (2012). Basic Health Research 2011. Jakarta

Ministry of Health RI. (2011). Malaria Epidemiology in Indonesia. Directorate General of PP and PL. Jakarta.

Notoatmodjo, S. (2012). Health Promotion and Health Behaviour. Jakarta. Rineka Cipta.

Ife, Jim \& Tesoriero, Frank. (2008). Community Development: Alternative Community Development in the Era of Globalization, Yogyakarta: Publisher of Student Library

Koch T.\& Kralik D. (2012). Participatory action research in health care. British: Blackwell publishing

Wafi, Nur \& Muslihatun. (2010). Neonatal Care. Yogyakarta. Fitramayana.

WHO. (2010). Guidelines for the treatment of malaria, Second edition, Geneva

Susana, D. (2010). Dynamics of Malaria Transmission. Jakarta. UI Press.

Harijanto PN, Agung. N \& Agung AG. (2012). Malaria from molecular to clinical. 2nd edition. Jakarta: ECG

Sorontou Y. (2014). Clinical malaria science. Jakarta: ECG

Mubarok Z. (2010). Evaluation of Community Empowerment Reviewed From Capacity Development Process in Pnpm Mandiri Urban Activities in Sastrodirjan Village, Pekalongan Regency. Thesis. Diponegoro University

Ministry of Health RI. (2009). Training Package Book of Health Cadres and Community Leaders in The Development of Standby Village

Notoatmodjo. 2010. Health Research Methodology, Jakarta. Rineka Cipta 